\title{
Tax burden reduction and tax cuts in China's vat reform
}

\author{
Yong Fan ${ }^{1, a}$, Haonan $\mathrm{Li}^{1, \mathrm{~b}}$, Qinyao $\mathrm{Zhu}^{1, \mathrm{c}}$ \\ ${ }^{1}$ Central University of Finance and Economics, Beijing, China \\ $a$ iD 0000-0002-1741-001X \\ ${ }^{b}$ iD $\underline{0000-0001-7748-665 X}$ \\ c iD $\underline{0000-0002-3647-5652}$
}

\begin{abstract}
The article discusses the impact of VAT reforms in China aimed at reducing tax burden. These include the VAT transformation, "replacement of the business tax with the VAT", and the simplification and consolidation of the tax rate. The purpose of our study is to describe the results of the VAT reforms and answer two questions: why is there so much controversy surrounding tax burden in the context of the "business tax to VAT" reform? and why are companies so concerned about the VAT reform? These questions can be answered if we analyze the four indicators of the VAT tax burden: the statutory tax rate, the effective tax rate, the nominal tax burden and the actual tax burden. These indicators can also be considered on three levels: macro-level (state or region), mid-level (industry), and micro-level (enterprises). The article illustrates the differences and relationships between these indicators and uses them to analyze the effect of the tax cuts. The input-output method is applied to analyze the indicators for the 2008-2015 period. All indicators of the VAT reform, except for the statutory tax rate, show a clear declining trend in terms of tax burden: the effective tax rate in various industries has dropped by about $1 \%$ to $10 \%$; the nominal tax burden, by about $0.5-5 \%$; the actual tax burden, by 150 billion yuan. Therefore, we recommend to reduce the VAT burden by establishing a VAT retained refund system and by increasing the actual deductible rate of enterprises.
\end{abstract}

\section{KEYWORDS}

value-added tax, VAT reform, business tax, statutory tax rate, effective tax rate, nominal tax burden, actual tax burden, input-output method

JEL H25, G28, P31

\section{Налоговая нагрузка и снижение налогов в рамках реформы НАС в Китае}

\author{
Фан Юн ${ }^{1, \text { a }}$, Ли Хаонан ${ }^{1,6}$, Джу Тсиняо ${ }^{1, ~ в ~}$ \\ ${ }^{1}$ Центральный университет финансов и экономики, Пекин, Китай \\ $a$ (iD) 0000-0002-1741-001X \\ ${ }^{\sigma}$ iD $\underline{0000-0001-7748-665 X}$ \\ ${ }^{8}$ iD $\underline{0000-0002-3647-5652}$
}

\begin{abstract}
АННОТАЦИЯ
В статье рассматривается влияние трансформации НДС в Китае на снижение налоговой нагрузки. Цель исследования - сформировать базовое понимание результатов реформы НДС и ответить на два вопроса: почему эмпирические исследования налогового бремени после замещения налога на бизнес налогом на добавленную стоимость дают противоречивые результаты; почему компании так обеспокоены реформой НДС. Анализируемые показатели налоговой нагрузки по НДС разделены на четыре типа (нормативная налоговая ставка, эффективная налоговая ставка, номинальная налоговая нагрузка и фактическая налоговая нагрузка) и три уровня (макро-уровень (страна, регион), мезо-уровень (отрасль) и микро-уровень (предприятие)). Статья иллюстрирует
\end{abstract}




\begin{abstract}
различия и внутреннюю логику взаимосвязи между выделенными типами показателей. Исследуются показатели налоговой нагрузки за 2008-2015 гг. с использованием метода вход-выход. Рассматривается эффект снижения налогов вследствие замены налога на бизнес налогом на добавленную стоимость, а также упрощения и консолидации налоговой ставки с использованием указанных четырех типов показателей. Сделан вывод, что все показатели налоговой нагрузки, за исключением нормативной налоговой ставки, имели значительную тенденцию к снижению: эффективная ставка налога в различных отраслях промышленности снизилась примерно на 1-10\%; номинальная налоговая нагрузка уменьшилась на 0,5-5\%; фактическая налоговая нагрузка также снизилась на 150 млрд юаней. Основываясь на результатах анализа, предложены рекомендации по дальнейшему снижению налоговой нагрузки по НДС, а также созданию системы возврата удержанного НДС и повышение фактического уровня вычета налога для предприятий.
\end{abstract}

\title{
КЛЮЧЕВЫЕ СЛОВА
}

НДС, нормативная налоговая ставка, эффективная налоговая ставка, номинальная налоговая нагрузка, фактическая налоговая нагрузка, метод затраты-выпуск

\section{Introduction}

In recent years, there has been a general trend of tax cuts to ensure economic recovery. This trend involves major economies such as the United States, Germany, and France, which have successively implemented or are going to implement reforms aimed at lowering taxes. China joined this international trend by introducing structural tax cuts in 2004. In 2011, the business tax was replaced with the VAT (the B2V reform). Since the turnover tax is the most important part of the tax system, the VAT reform has undoubtedly been one of the most significant tax reforms since the major overhaul of 1994. Objectively, the VAT reform has allowed the government to reduce tax burden and provide a model for other countries ${ }^{1}$. According to the statistics published by China's tax authorities, these two tax reforms resulted in more than 1.2 trillion yuan in tax cuts [1, p. 75]. In the 2016 Government Work Report, Premier Li Keqiang emphasized that the full implementation of the B2V reform should ensure the reduction of the tax burden in every sector of economy. However, the reform met some resistance from certain industries and enterprises, and a research report about a

1 Pascal Santana, director of the OECD's Tax Policy and Management Center said, "This is a major reform, and the results we have seen so far are very positive and significant. The reforms have advanced well and meet the highest standards of the world". "death tax rate" was published [2], which had some serious social repercussions. On the one hand, the tax revenue showed a continuous decline; on the other, enterprises complained about a higher tax burden. Actually, there are two questions behind these contradictory arguments. First, if any changes in tax burden can be measured, why is there so much controversy surrounding the VAT reform? Second, seen from a theoretical perspective, the VAT is a general consumption tax borne by consumers, but then why are companies so concerned about it?

One of the reasons for the controversy around China's VAT reform is that the key aspects of how the VAT tax burden should be measured are still unclear. Tax burden is a basic concept of taxation theory and it is also the core indicator used to analyze the relationship between taxation and economic growth. The measurement and the use of the VAT tax burden are directly related to how we understand the VAT and how we measure the effect of tax cuts. Although there is vast research literature on tax burden, there is still no unified opinion on this subject and different concepts may be used to study it, for example, the statutory tax rate, nominal tax rate, effective tax rate, nominal tax burden, actual tax burden and effective tax rate. Moreover, for the same concept different researchers may apply different measurement standards. The above-described situation results in a diversity of contradictory 
opinions on the subject. Another, underexplored question is measurement of the VAT, which may affect our understanding of the matters concerning the progress and direction of VAT reforms.

Focusing on the above-mentioned disputes, in this article we are going to clarify the theoretical aspects of the measurement of the VAT tax burden and prove the opinion that the VAT reform should be based on complete understanding of all the three levels of the VAT burden - macro-, mid- and micro-level and its four key indicators - the statutory tax rate, the effective tax rate, the nominal tax burden and the actual tax burden. This article describes each indicator, illustrating the differences between them and demonstrating their intrinsic logic by using the input-output method.

The subsequent sections will be arranged as follows. Section 2 presents a literature review. Section 3 studies the four different categories of tax burden - statutory tax rate, effective tax rate, nominal tax burden, and actual tax burden - and analyzes the relationship between them. Section 4 examines the tax cut effects of the VAT transformation, the B2V reform, and the simplification and consolidation of the tax rate. Section 5 contains a conclusion and policy recommendations.

\section{Literature review}

At present, there are about 60,000 articles concerning VAT tax burden, their authors using various types of indicators to prove their opinions. The choice of the indicator also usually depends on the data available for research. Furthermore, the documents issued by the government rely on indicators different from those used in theoretical studies. In Table 1 , we summarize some of the indicators used in research literature and in official documents. The concept of the actual tax burden rate and the industry tax burden mentioned in the documents of the Ministry of Finance and State Administration of Taxation No. 111 of 2011 and Ministry of Finance and State Administration of Taxation No. 86 of 2012 was used to cope with the temporary rise in the tax burden after the VAT reform. According to the documents, providers of pipeline transportation services and tangible and movable property financial lease services, on which the tax burden exceeded $3 \%$, would qualify for a refund upon collection; here the tax burden means the proportion of the VAT paid by the taxpayers as a part of the total charges during the current period. The tax burden mentioned in the 2016 Government Work Report by Premier Li Keqiang is the measurement indicator normally used in official documents.

Research literature uses various concepts, including industry tax burdens [3, p. 109; 4, p. 13; 5, p. 32], actual tax burden or actual tax burden rate [6, p. 19], nominal tax burden [6, p. 19], effective tax rate $[7, \mathrm{p} .84]$, and corporate tax burden [8, p. 90]. Furthermore, sometimes even though the same concept is used, its actual meaning and ways of calculation vary from study to study. For example, Fan Ziying [8, p. 83] estimated the corporate tax burden by using education surcharges to retroactively implement the turnover tax and then deduct the consumption tax. In studies using the concept of the industry tax burden, Liu Daimin and Zhang Biqiong [3, p. 108] applied the concept of the turnover tax plus income tax, Jiang Mingyao [4, p. 12] used the proportion of the adjusted VAT to added value, and Tian Zhiwei and Hu Yijian [5, p. 30] calculated the ratio of the VAT and business tax to the total output of the industry as the industry tax burden. Since there are different measurement standards, the assessment of the change in tax burden after the VAT reform can be different or sometimes even contradictory. For example, Wang Yulan and Li Yakun [9, p. 43] believed that the tax burden of the service industry may increase without purchasing fixed assets. Huang Guilan [10, p. 11] calculated the tax burden of 81 companies and found that the tax burden on companies working in the sphere of road transportation and logistics increased significantly. Yang Zhiyong [11] and Tong Jinzhi [6, p. 26] also believed that the tax burden will rise in all sectors. On the contrary, Liu Daimin and Zhang Biqiong [3, p. 112] and Tian Zhi- 
wei and Hu Yijian [5, p. 34] held the opinion that the tax burden would decrease. Li Xiaocan [12, p. 195] pointed out that the overall tax burden of the transportation industry can be reduced through the VAT reform. Some scholars believe that in some sectors the tax burden may increase while in others, on the contrary, decrease $[8$, p. $95 ; 4$, p. $16 ; 13$, p. $105 ; 14$, p. $121 ; 15$, p. 295]. Fu Limin [16] believes that enterprises can enjoy the benefits of the reform depends on whether the deductible proj- ect is sufficient and whether the impact of different deduction systems on the tax burden of various industries is different [17, p. 41]. In general, different approaches to measuring tax burden result in the following: first, there is no unified concept to be used in governmental documents and research literature; second, the concept of tax burden as such may acquire different meanings in different studies; and third, there discrepancies in calculations may result from the lack of unified algorithms or

Usage of VAT tax burden in government documents and relevant literature

\begin{tabular}{|c|c|c|c|}
\hline \multicolumn{4}{|c|}{ Government documents } \\
\hline Sources & $\begin{array}{l}\text { Concept of tax } \\
\text { burden }\end{array}$ & \multicolumn{2}{|l|}{ Meaning } \\
\hline $\begin{array}{l}2016 \text { Government Work } \\
\text { Report }\end{array}$ & \multirow{3}{*}{$\begin{array}{l}\text { Industry } \\
\text { tax burden, } \\
\text { effective tax rate }\end{array}$} & \multirow{2}{*}{\multicolumn{2}{|c|}{ Paid VAT }} \\
\hline $\begin{array}{l}\text { Ministry of Finance and } \\
\text { State Administration of }\end{array}$ & & & \\
\hline \begin{tabular}{|l|} 
Taxation No. 111 of 2011 \\
Ministry of Finance and \\
State Administration of \\
Taxation No. 86 of 2012 \\
\end{tabular} & & \multicolumn{2}{|c|}{ All fees and charges incurred for the current taxable services } \\
\hline \multicolumn{4}{|c|}{ Literature } \\
\hline Sources & $\begin{array}{l}\text { Concept of tax } \\
\text { burden }\end{array}$ & Meaning & Conclusion \\
\hline \multirow[t]{2}{*}{ Fan Ziying (2017) } & \multirow[t]{2}{*}{$\begin{array}{l}\text { Corporate tax } \\
\text { burden }\end{array}$} & $\begin{array}{l}\text { Turnover tax reversed by education } \\
\text { surcharges - Consumption tax }\end{array}$ & \multirow{2}{*}{$\begin{array}{l}\text { Industrial enterprises } \\
\text { obviously benefit from } \\
\text { the tax reduction effect }\end{array}$} \\
\hline & & Revenue & \\
\hline Chen Xiaoguang & Effective tax & Paid VAT & The difference in tax \\
\hline$(2013)$ & rate & $\overline{\text { Added value }}$ & $\begin{array}{l}\text { rates leads to efficiency } \\
\text { loss }\end{array}$ \\
\hline \multirow{2}{*}{ Jiang Mingyao (2011) } & \multirow{2}{*}{$\begin{array}{l}\text { Industry tax } \\
\text { burden, average } \\
\text { tax burden }\end{array}$} & Adjusted VAT (or Business tax) & \multirow{2}{*}{$\begin{array}{l}\text { The average tax } \\
\text { burden on the industry } \\
\text { is reduced, and the } \\
\text { average tax burden on } \\
\text { the service industry is } \\
\text { significantly increased }\end{array}$} \\
\hline & & Added value & \\
\hline $\begin{array}{l}\text { Liu Daiming and } \\
\text { Zhang Biqiong (2015) }\end{array}$ & $\begin{array}{l}\text { Industry tax } \\
\text { burden }\end{array}$ & $\begin{array}{c}\text { Sum of turnover tax and income } \\
\text { tax (absolute value) }\end{array}$ & $\begin{array}{l}\text { The tax burden on } \\
\text { commercial banks } \\
\text { is reduced after } \\
\text { the business tax is } \\
\text { replaced with the VAT }\end{array}$ \\
\hline $\begin{array}{l}\text { Tian Zhiwei and Hu } \\
\text { Yijian (2013) }\end{array}$ & $\begin{array}{l}\text { Industry tax } \\
\text { burden }\end{array}$ & $\frac{V A T+\text { Business tax }}{\text { Total industry output }}$ & $\begin{array}{l}\text { The tax burden on } \\
\text { the service industry is } \\
\text { reduced, and there is } \\
\text { a limited reduction in } \\
\text { the tax burden on the } \\
\text { original VAT industry }\end{array}$ \\
\hline $\begin{array}{l}\text { Wang Yulan and } \\
\text { Liyakun (2014) }\end{array}$ & $\begin{array}{l}\text { Turnover tax } \\
\text { burden, income } \\
\text { tax burden }\end{array}$ & $\frac{\text { Turnover tax or income tax }}{\text { Revenue }}$ & $\begin{array}{l}\text { The tax burden on the } \\
\text { service industry may } \\
\text { rise }\end{array}$ \\
\hline $\begin{array}{l}\text { Tong Jinzhi et al. } \\
\text { (2015) }\end{array}$ & $\begin{array}{l}\text { Nominal tax } \\
\text { burden, effective } \\
\text { tax burden }\end{array}$ & $\begin{array}{l}\text { Turnover tax burden } \\
\text { (considering tax shifting) }\end{array}$ & $\begin{array}{l}\text { The turnover tax } \\
\text { burden on various } \\
\text { industries increases }\end{array}$ \\
\hline
\end{tabular}


sources of data. All these aspects seriously affect our understanding of the VAT tax burden.

Moreover, the lack of common understanding as to how tax burden should be measured is felt not only in VAT reform studies but also in the studies of VAT tax burden. After reviewing the existing literature, Fullerton $[18$, p. 26] classified the effective tax rate (ETR) into six forms - the average effective corporate tax rate, the average effective total tax rate, the marginal effective corporate tax wedge, the marginal effective corporate tax rate, the marginal effective total tax wedge, and the marginal effective total tax rate. Yang Jingzhong [19, p. 114] analyzed unequal tax burdens and tax management of tourism enterprises. He defined the nominal tax burden as the tax rate prescribed by the tax law and the actual tax burden as the ratio of the actual tax bill to the real income. Chen Xiaoguang [7, p. 70] calculated the effective tax rate as the amount of the VAT that the company actually paid as compared to the added value and used this ratio to study the efficiency loss caused by the differences in the VAT rate. Thus, the lack of unified terminology makes research results incomparable and may have misleading effects on policymaking decisions.

Compared with studies of other taxes, there are very few articles focusing on the indicator of the VAT, and, as far as we can judge, none of them describes different indicators in detail. Not only is this kind of clarification important to gain an accurate understanding of China's fiscal and taxation reform, but it is also essential for ensuring an actual tax reduction and determining the future direction of the reform. In this article, we are going to fill some of the research gaps in this regard and offer clarification of these concepts.

\section{Definition of the VAT tax burden}

\subsection{The concept of tax burden}

Based on the combination of the general principles behind the VAT and the implementation of the VAT system, the VAT tax burden can be divided into four indicators: the statutory tax rate, the effective tax rate, the nominal tax burden, and the effective tax burden².

Although the four indicators differ from one another, they are interconnected and can influence each other.

The first indicator is the statutory tax rate of the VAT, which refers to the collection proportion of the VAT specified by the state in the tax laws. It is the fundamental basis of calculating VAT payments (including the calculation of output and deduction taxes), and it is the first type of indicator reflecting the VAT burden. In the same country or region, the same statutory tax rate applies to the same industries or companies that manufacture a product. The simpler the statutory tax rate structure is, the more industries and corporations apply the same tax rate, which reflects the horizontal equity principle of taxation ${ }^{3}$.

In the modern national economic accounting system, the calculation indicator of the added value (GDP) created by a region or country in a certain period is consistent and regular. Therefore, in the countries or regions where VAT collection models are applied, the statutory tax rate of the VAT has become a measure of the scale of value-added taxation of a country or region, reflecting the VAT tax burden on the macroeconomic level. The level of the statutory tax rate of the VAT is mainly determined by the country's regional level of economic development, taxation structure, and historical tax burden. The higher the tax rate is, the more VAT will be levied, and vice versa. Since statutory tax rates are stipulated by tax laws in various countries and are easy to find, they are often used to compare VAT levels in various countries. However, due to the differences in specific VAT systems, collection and management capabilities, and methods of tax collection and administration in various countries, the statutory tax rate of the

${ }^{2}$ Although some studies use slightly different indicators, these indicators can still fit into these four categories through the general principle of the VAT.

3 However, this is not a true horizontal equity principle, because the statutory tax rate is not equal to the effective tax burden. 
VAT cannot fully reflect the macro-level VAT burden and does not even reflect the characteristics of VAT burdens in different industries.

The second indicator is the effective tax rate of the VAT. It is based on the statutory tax rate of the VAT and calculates the ratio of theoretical VAT payable and VAT basis according to the method stipulated by the VAT system. The effective tax rate is a kind of the general tax rate on the medium industry level and is determined by the input and output structure (i.e. deduction structure $)^{4}$. The effective tax rate is the second type of indicator reflecting the level of taxation of the VAT, especially the VAT burden on different industries or enterprises that produce the same type of products. According to the principle of VAT calculation, the effective tax rate is affected by the statutory tax rate and the VAT tax rate grades. In an ideal situation, the effective tax rate should be equal to the statutory tax rate, but there is often a difference between the statutory tax rate and the effective tax rate within a specific VAT system. The effective tax rate needs to be calculated according to a particular system and characteristics of the industry, which is more difficult than in the case of the statutory tax rate, but it reflects the VAT tax burden more objectively. In the practice of taxation, tax authorities and enterprises use the ratio of paid VAT and the sales revenue of enterprises to calculate the effective tax rate. The problem, however, is that this calculation method may use different samples and different periods of ownership, which means that the results may vary and sometimes be neither representative nor comparable. In the context of China's VAT system, it is more important to calculate the effective VAT rates of various industries by using the input and output tables regularly compiled in China. The statutory tax rate remains the same or decreases, the scope of VAT deduction expands as the scope of VAT collection ex-

${ }^{4}$ The change of the structure of deduction, which is affected by practical factors such as the production cycle, does not belong to the category of the effective tax rate. Real tax rates are a more general concept. pands, and the effective VAT rate will definitely decrease. This is the internal logic of the $\mathrm{B} 2 \mathrm{~V}$ reform meant to reduce rather than increase the VAT in all industries.

The third indicator is the nominal VAT burden. The nominal VAT burden refers to the economic burden on taxpayers for the actual payment of the VAT, which may be borne or may be passed on. Therefore, the nominal tax burden does not always accurately reflect the effective tax burden. As a turnover tax, the VAT may require taxpayers to pay a certain amount of value-added tax at each circulation. This is the third category of indicator reflecting the burden of the VAT. The VAT is an indirect tax, and VAT payers are not the same as tax bearers. Therefore, the VAT tax burden can be divided into the nominal tax and effective tax burdens. For the convenience of measurement, the nominal tax value of the VAT is generally measured by the ratio of the VAT payable during the inspection period to certain economic indicators (e.g., added value, sales revenue, and profits) during the same period. This ratio is mainly affected by two factors: the first is the effective tax rate; that is, taxpayers engaged in different industries may pay different proportions of the VAT due to different effective VAT rates; the second is the collection rate and tax incentives, including various factors such as the VAT management level of taxpayers and tax authorities, various tax incentives, and so on. This is the basic principle of the VAT, and it exists in all countries where the VAT is imposed. For example, the VAT collection rate in any country is unlikely to be $100 \%$, as there will be different levels of tax losses. In 2009, the VAT tax loss rate in the UK was around $10-15 \%$, and in 2012, Sweden's VAT tax loss rate was about 14\% [20, p. 48]. Considering the existence of a tax gap, the nominal VAT tax burden should be lower than the effective VAT rate in an industry's business cycle. In reality, due to different selected periods, the VAT nominal tax burden may also be higher than the industry's effective tax rate (the tax paid is more than the current tax payable), or it may be lower than the industry's effective 
tax rate (the paid tax is less than the current tax payable), which is directly related to the selected industry or company at different points in their operating cycle.

The fourth (and the most objective) indicator is the actual VAT burden, which refers to the economic burden on the tax bearers. From the theoretical perspective, the VAT is usually considered to be a consumption tax, with the tax burden fully passed on to consumers. That is to say, it is not the manufacturers of goods or providers of services that are the ultimate VAT bearers but the consumers. Therefore, the concept of VAT burden applies only to consumers and has no impact on others. Enterprises in those countries that have the VAT do not pay attention to the VAT burden. In this case, the measurement of the VAT burden is relatively simple. The absolute amount of the tax burden is equal to the product of the amount of consumer consumption and the statutory tax rate, and the relative amount of tax burden under the single tax rate is equal to the statutory tax and effective tax rates.

There are, however, some studies that show that the VAT is not entirely borne by consumers but is shared by consumers and producers (Matti Viren [22, p. 130], Smart and Bird [23, p. 600]). The reasons why the tax burden cannot be fully passed on to consumers are as follows. First and foremost, the VAT affects people's con- sumption decisions, which means that it is not a completely neutral tax and that its why it cannot be fully passed on. Second, if a comprehensive VAT refund system is not established and the company has stocks or slow-moving goods, it will bear the tax burden of the previous link within a certain period. Third, even if a company can fully shift the tax burden, paying the tax will also create an economic burden on the company. The longer the tax return period is, the more obvious is the burden, especially if the product is slow-moving or the input tax exceeds the output tax. Therefore, the effective tax burden is different from the nominal tax burden. If we also take into consideration the factor of tax shifting, the tax burden actually borne by the company will be less than the nominal tax burden. However, when calculating the effective tax burden, the transfer factor is often overlooked and only the nominal tax burden is considered.

\subsection{Relationships among indicators}

Of the four indicators of the VAT tax burden, the effective tax rate and nominal tax rate are more commonly used, while the statutory tax rate, due to its simplicity, is also used to compare the tax burden. Although there are differences between these indicators, they have their own internal logic. Figure 1 clearly shows this relationship.

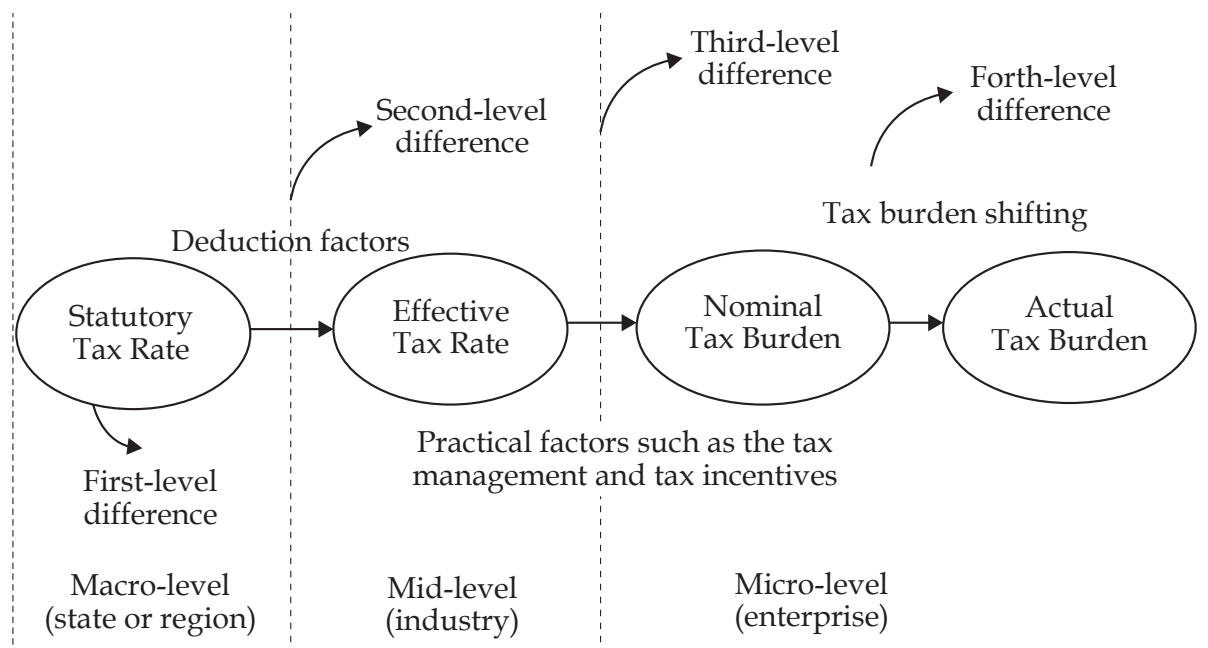

Figure 1. Relationship between the statutory tax rate, actual tax rate, nominal tax burden, and actual tax burden 
China's VAT has a multi-level tax rate. It has different applicable tax rates for different industries and taxpayers, which are the main indicators of the macro-tax burden. Thus, the calculation of the effective tax rate is based on the VAT system and the input-output structure. It is affected by both the statutory tax rate and the deductible structure and reflects the general level of the tax burden on the industry. The nominal tax burden is the actual tax paid by the taxpayer. In the process of tax collection and management, it will be affected by various practical factors such as tax incentives, tax collection, and management $^{5}$. The relationship between the effective tax rate and the nominal tax burden shows a transition from theory to practice. Finally, since the taxpayer is not the same as the tax bearer, the tax actually paid by the taxpayer does not equal the tax actually borne. The nominal tax burden can be transferred to the actual tax burden through tax shifting. The nominal tax burden and the actual tax burden reflect the tax burden on the micro-level. On the whole, the effective tax rate is the statutory tax rate that considers the deduction factor; the nominal tax burden is the actual tax rate that takes into account actual factors; and the actual tax liability is the nominal tax liability that takes into account the tax shifting factor. The deductible factors, actual factors, and shifting factors vary depending on periods, industries, and taxpayers. Therefore, there will be four levels of differences, resulting in different effective tax burdens borne by different taxpayers.

Let the statutory tax rate be $r$ and the effective tax rate, nominal tax burden, and effective tax burden be $r_{1}, r_{2}$, and $r_{3}$, respectively. According to the above-described

5 These factors do not merely include the issues of simple concessions and collection rates. They may include, for example, some "extra" concessions, tax competition, taxation "cisterns", and other human factors. The real factors will also include, for example, the actual factors of deduction. As the deduction tax can only be obtained during the tax return period, even under the same factor input structure, the industry deduction rate will be different in different periods due to different factor input cycles. analysis, the relationship among the four tax burden indicators can be expressed by the following equation:

$$
r_{1}=\frac{r_{\text {out }} Y_{\text {out }}-r_{\text {in }} Y_{\text {in }}}{\vartheta} .
$$

Formula (1) only shows the case when there is only one taxable product. Among them, the statutory tax rate (output tax) is $r_{\text {out }}$, the statutory tax rate (input tax) is $r_{i n}$, the input and sales income are $Y_{i n}$ and $Y_{\text {out }}$ and $\vartheta$ is the added value (the difference between $Y_{\text {out }}$ and $Y_{\text {in }}$ ). While all intermediate inputs in the VAT system can be deducted, in the actual VAT system, the intermediate inputs cannot be fully deducted, so the added value is represented by a separate symbol. In Formula (1), the denominator is the added value, and the numerator is the output tax minus the input tax, which reflects the general principle of the VAT system. If sales revenue is used as the denominator, the effective tax rate is not equal to the statutory tax rate even if the output tax rate is equal to the input tax rate.

$$
r_{2}=\mu r_{1} .
$$

Ratio $\mu$ represents the difference between theory and reality, and it represents the actual factors such as tax collection and tax incentives as well as other unobservable factors. This shows that the difference between the effective tax burden and the nominal tax burden stems from the various factors of transition from theory to reality.

$$
r_{3}=(1-\delta) r_{2}
$$

$\delta$ represents the coefficient of tax shifting. The more the tax burden is shifted, the lower is the effective tax burden, while the less the tax burden is shifted, the higher is the effective tax burden. When the tax burden is completely shifted, the nominal tax burden is meaningless because the effective tax burden is not borne by the taxpayer. Otherwise, the nominal tax burden is equal to the actual tax burden.

The combination of Formulae (1), (2), and (3) can yield the relationship between the actual tax burden and the statutory tax rate. 


$$
r_{3}=(1-\delta) \mu \frac{r_{\text {out }} Y_{\text {out }}-r_{\text {in }} Y_{\text {in }}}{\vartheta} .
$$

It can be seen from Formula (4) that the actual tax burden depends on the deductible structure, the practical factors, and the tax burden shifting factors, which is identical to the relationship presented in Figure 1. The actual tax burden is equal to the statuary tax rate only when the deductible chain is complete; the output tax rate equals the input tax rate $\left(r_{\text {out }}=r_{\text {in }}\right)$; there is no difference between reality and theory $(\mu=1)$ and no tax burden shifting $(\delta=1)$. It is obvious that under the current tax system, these conditions cannot be fully satisfied, so the actual tax burden is different from the statutory tax rate and other tax burden indicators.

The intuitive answers to the two above-mentioned puzzles can be drawn by analyzing Figure 1 and Formula (4). Firstly, why are there so many contradictory empirical research findings and views about tax burdens after the reform aimed at "replacing the business tax with the VAT"? One important reason is that the indicators used in research may vary. For example, the VAT tax burden indicator used in government documents mentioned in Table 1, Fan Ziying [8, p. 87], Chen Xiaoguang [7, p. 83], Jiang Mingyao [4, p. 13], Liu Daimin and Zhang Biqiong [3, p. 109], Tian Zhiwei and Hu Yijian [5, p. 31], and Wang Yulan and $\mathrm{Li}$ Yakun [9, p. 42] can be clarified as the nominal tax or something similar, and this indicator considers no shifting factors. Tong Jinzhi [6, p. 17] used the actual tax burden (considering the shifting factor) while the statutory tax rate and the effective tax rate are widely used in practice and by companies. Thus, it is the difference in cindicators used that creates controversy about tax cuts in the academia, business and the government. Moreover, the VAT is a general excise tax, but due to incomplete shifting, companies also bear some of the VAT. Therefore, it can be concluded that we should neither demonize the tax burden calling it the "death tax rate" nor ignore the VAT borne by companies.

\section{Tax indicators and tax cuts}

\subsection{Calculation methods and data sources of tax burdens}

according to the general principle of the VAT and various practical factors of tax implementation, the VAT tax burden indicators can be divided into four types: the statutory tax rate, the effective tax rate, the nominal tax burden, and the actual tax burden. This section uses some data to illustrate our understanding of tax reductions from the perspective of different indicators and provides answers to the questions mentioned at the beginning of this article regarding which types of tax reductions are more effective.

\subsubsection{Calculation of the effective tax rate}

Calculation of the effective tax rate is mainly based on the input-output table. This article has made some improvements based on the method proposed by Fan Yong [17].

Assuming $r_{1}^{i}$ is the actual VAT tax rate of sector, $Y_{\text {out }}^{i}$ is the total output of $j$ sector, $Y_{i n}^{i j}$ is the products or services of $j$ sector but consumed by $i$ sector, $r_{i n}^{j}$ and $r_{\text {out }}^{j}$ are the $j$ sector's statutory tax rate (input) and statutory tax rate (output), respectively, and $a_{i j}$ is the direct consumption coefficient. Based on the concept, the ratio of $j$ sector's products or services consumed in order to produce one unit of product of $i$ sector to the total investment is as follows:

$$
a_{i j}=\frac{Y_{i n}^{i j}}{\sum_{j} Y_{i n}^{i j}},
$$

$\lambda$ and $\mu$ represent the VAT output tax and input tax respectively, and $\lambda_{i}$ is the output tax in $i$ industry.

$$
\lambda_{i}=Y_{\text {out }}^{i} r_{\text {out }}^{i} .
$$

$\mu_{i j}$ represents the input tax of $i$ sector, which comes from $j$ sector.

$$
\mu_{i j}=Y_{i n}^{i j} r_{i n}^{j} .
$$

According to the concept of the effective tax rate, we assume that $r_{1}^{i}$ is the effective tax rate of sector $i$ (the added value is the denominator):

$$
r_{1}^{i}=\frac{\lambda_{i}-\sum_{j} \mu_{i j}}{\vartheta_{i}} .
$$


We substitute Equations (6) and (7) into Equation (8):

$$
r_{1}^{i}=\frac{Y_{\text {out }}^{i} r_{\text {out }}^{i}-\sum_{j} Y_{\text {in }}^{i j} r_{\text {in }}^{j}}{Y_{\text {out }}^{i}} \cdot \frac{Y_{\text {out }}^{i}}{\vartheta_{i}}
$$

simplified as

$$
\begin{aligned}
r_{1}^{i} & =\left(r_{\text {out }}^{i}-\sum_{j} \frac{Y_{\text {in }}^{i j}}{Y_{\text {out }}^{i}} r_{\text {in }}^{j}\right) \frac{Y_{\text {out }}^{i}}{\vartheta_{i}}= \\
& =\left(r_{\text {out }}^{i}-\sum_{j} a_{\text {ij }} r_{\text {in }}^{j}\right) \frac{Y_{\text {out }}^{i}}{\vartheta_{i}} .
\end{aligned}
$$

When comparing the original business tax rate, the nominal tax burden $r_{1}^{i^{*}}$, which uses sales income as the denominator, is as follows:

$$
r_{1}^{i^{*}}=r_{\text {out }}^{i}-\sum_{j} a_{i j} r_{i n}^{j} .
$$

The effective tax rate does not take into account practical factors. Therefore, it is unnecessary to exclude from our calculations import and export factors, differences in total output, sales revenue, and tax incentives. In order to visually show the effect of the B2V reform on the effective tax rate and eliminate the influence of the input-output structure, this article adopted the 2012 Input-Output Table when calculating all the data. Based on Formulae (10) and (11), the 2012 Input-Output Table and the statutory tax rates of all sectors, the effective tax rate can be calculated. Since fixed asset investments cannot be deducted until the VAT transformation, we deducted the proportion of the depreciation of fixed assets in all sectors to the total investment ${ }^{6}$. However, we used the statutory tax rate to calculate the effect of the B2V reform and the simplification and consolidation of the tax rate. When there are several statutory tax rates for one sector, we choose the one with a relatively larger proportion ${ }^{7}$.

${ }^{6}$ The effective tax rate is a general tax rate, so there is no need to consider periodic fixed assets investment.

${ }^{7}$ For example, let us take a look at the leasing and business service sector. The statutory tax rates of tangible property leasing and real estate leasing are $17 \%$ and $11 \%$ respectively, while the business services are $6 \%$. Since the tax paid by the leasing industry only accounts for $2.5 \%$, we choose $6 \%$ as the statutory tax rate for this industry.

\subsubsection{Calculation of the nominal tax burden}

$r_{2}^{i}$ represents the nominal tax burden of sector $i$ and $t_{i}$ is the VAT actually paid by sector $i$. Therefore,

$$
r_{2}^{i}=\frac{t_{i}}{\vartheta_{i}}
$$

The nominal tax burden can be calculated according to Formula (12). The data of the VAT paid by all the industries come from the 2009-2016 China Tax Yearbook, and the added value comes from the 2009-2016 China Statistical Yearbook.

\subsection{Statutory tax rate}

As a result of the B2V reform, there are now five types of statutory tax rates $17 \%, 13 \%, 11 \%, 6 \%$, and zero; in addition, there are two types of the leviable rate $3 \%$ and $5 \%$. Among these, the rate of $17 \%$ applies to the majority of situations, including sales or import of most goods, processing, repair, and replacement services, and tangible property leasing services. For taxpayers selling or importing goods, such as food grains, books, newspapers, feeds, and chemical fertilizers, the tax rate shall be $13 \%$. For those who provide taxable services, the tax rate shall be $11 \%$ or $6 \%$; for example, those who provide life services, financial services, valueadded telecommunication services, and sales of intangible assets, the tax rate shall be $6 \%$. Finally, the zero tax rate applies to services such as international and space transportation.

Most other countries that have the VAT use either a single tax rate or multiple tax rates. The VAT rates of some of these countries are shown in Figure 2; the black dotted line in the figure shows the $17 \%$ tax rate 9 .

From the perspective of tax rate, China's $17 \%$ tax rate is at a moderately low level; the VAT rates for most OECD countries such as Austria, Belgium, Denmark, and France are between 20\% and 25\%,

${ }^{8}$ After July 1, 2017, the rate of $13 \%$ was replaced by $11 \%$.

${ }^{9}$ According to the data released by IBFD in 2016, this article uses the most common tax rate for those who have multiple rates. 


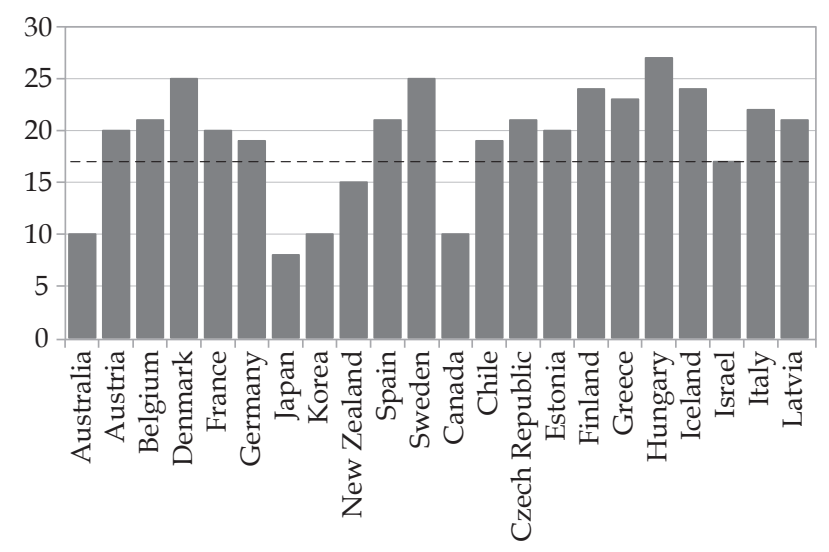

Figure 2. Worldwide statutory tax rates

and only the tax rates of Australia, Japan, South Korea, and Canada are less than $17 \%$. However, this kind of comparison is not very effective as it cannot be used as a standard to measure the actual tax burdens in all countries. For example, although the tax rate in Denmark is $25 \%$, when calculating the VAT, we only take $20 \%$ of the price into account. As a result, the effective tax rate is much lower than $25 \%$.

The tax rate after the $\mathrm{B} 2 \mathrm{~V}$ reform is higher than the previously applicable business tax rate, while the related regulations imposed on July 1, 2017 are aimed at reducing the statutory tax rate by replacing the rate of $13 \%$ with $11 \%$. According to (13):

$$
r_{3}=(1-\delta) \mu \frac{r_{\text {out }} Y_{\text {out }}-r_{\text {in }} Y_{\text {in }}}{\vartheta} .
$$

A rise (or decrease) in the statutory tax rate is shown as an increase of $r_{\text {out }}$ (or a decrease in $r_{i n}$ ). Even assuming that an increase (or decrease) of the statutory tax rate does not affect any other variable, a rise (or decrease) of the output tax rate $r_{\text {out }}$ would lead to a decrease (or increase) of the actual tax burden while an increase (or decrease) of the input tax rate may cause an increase (or decrease) of the actual tax burden due to the reduction in the deductible input. As a result, it cannot actually reduce the tax burden ${ }^{10}$. In fact, changes in the statutory tax rate may also affect other

\footnotetext{
${ }^{10}$ Among those spheres to which the $13 \%$ tax rate applies, books and newspapers could be a part of the deductible input.
}

variables, and whether the actual tax burden would decrease or not is uncertain. From this point of view, at least from the perspective of tax cuts, it is not effective to reduce the statutory tax rate if we want to ensure tax cuts. Furthermore, it may make the situation worse by increasing the burden on enterprises.

\subsection{Effective tax rate}

The effective tax rate results from the combination of a VAT system and an input-output structure and is a general tax rate based on VAT theory. The effective tax rate does not consider actual factors and is only a theoretical tax rate calculated by taking into account the input-output structure and the design of the VAT system. It is the indicator that best reflects the design factors of the tax system. Tables 3 and 4 show the effective tax rate of the original VAT industry, the original business tax industry before and after the VAT transformation, after the B2V reform and after simplification and consolidation of the tax rate ${ }^{11}$.

If we analyze the data in Table 2, we shall see that the effective tax rate of the original VAT industry has decreased after the VAT transformation and the B2V reform, while increasing and decreasing after the simplification and consolidation of the tax rate. Among these, the $\mathrm{B} 2 \mathrm{~V}$ re-

11 For convenience, the description of the method of calculating the effective tax rate and the nominal tax burden is enclosed in the appendix. 
form has the most obvious effect: there is a $1.2-3.4 \%$ decrease in the effective tax rate, while the VAT transformation only dropped by $0.1 \%$ to $2.9 \%$. The intrinsic logic is that both of these reforms expand the scope of VAT deductions. The increase of input tax deductions can ensure a decrease of the effective tax rate in the original VAT industry. Since the expanding scope of "replacing the business tax with the VAT" is larger than that of the VAT transformation, the effect of the latter is also more obvious.
However, the logic of simplification and consolidation of the tax rate is less obvious. There has been, however, a decrease in the effective tax rate in these industries (e.g., the effective tax rate in the mining industry has decreased by $0.5 \% 12$ and the effective tax rate for production and supply of electricity, heat, gas, and water has dropped by about $3.5 \%$ to $5.1 \%$ ) since the statutory tax rate for the $13 \%$ tax rate industry was replaced by $11 \%$. This industry.

${ }^{12}$ Liquefied petroleum gas in the mining

Table 2

The effective tax rate in the original VAT industries

\begin{tabular}{|l|r|r|r|r|}
\hline \multirow{2}{*}{ Sector } & \multicolumn{4}{|c|}{ Tax Rate (\%) } \\
\cline { 2 - 5 } & $\begin{array}{c}\text { Before VAT } \\
\text { transforma- } \\
\text { tion }\end{array}$ & $\begin{array}{c}\text { After VAT } \\
\text { transforma- } \\
\text { tion }\end{array}$ & $\begin{array}{c}\text { B2V } \\
\text { reform }\end{array}$ & $\begin{array}{c}\text { Simplification \& } \\
\text { consolidation of } \\
\text { the tax rate }\end{array}$ \\
\hline Mining & 19.99 & 19.37 & 18.14 & 17.66 \\
\hline Manufacturing & 26.79 & 24.76 & 22.68 & 23.77 \\
\hline $\begin{array}{l}\text { Production and supply of electricity } \\
\text { and heat }\end{array}$ & 14.07 & 11.78 & 9.90 & 4.77 \\
\hline Production and supply of gas & 18.38 & 15.46 & 13.14 & 9.26 \\
\hline Production and supply of water & 15.33 & 14.36 & 12.75 & 9.28 \\
\hline Wholesale and retail trade & 22.54 & 22.44 & 20.17 & 20.20 \\
\hline $\begin{array}{l}\text { Management of water conservation, } \\
\text { the environment, and public facilities }\end{array}$ & 27.06 & 26.52 & 23.16 & 23.66 \\
\hline $\begin{array}{l}\text { Public management, social security, } \\
\text { and social organizations }\end{array}$ & 23.22 & 23.01 & 20.68 & 20.71 \\
\hline
\end{tabular}

Note: To ensure the consistency of the indicator, the effective tax rate for the mining industry and manufacturing industry is calculated by using the total investment as a weight.

The effective tax rate of the original business tax industry

Table 3

\begin{tabular}{|l|r|r|r|}
\hline \multirow{2}{*}{ Sector } & \multicolumn{3}{c|}{ Tax rate (\%) } \\
\cline { 2 - 4 } & $\begin{array}{c}\text { Before the } \\
\text { B2V reform }\end{array}$ & $\begin{array}{c}\text { After the } \\
\text { B2V reform }\end{array}$ & $\begin{array}{c}\text { Simplification and } \\
\text { consolidation of tax rate }\end{array}$ \\
\hline Construction & 3 & -0.11 & 0.06 \\
\hline Transport, storage, and post & 3 & 7.82 & 8.01 \\
\hline Hotels and catering services & 5 & -7.22 & -6.62 \\
\hline Information transmission, software, and IT & 3 & -0.22 & -0.16 \\
\hline Financial intermediation & 5 & 3.94 & 3.96 \\
\hline Real estate & 5 & 11.83 & 11.85 \\
\hline Leasing and business services & 5 & -9.45 & -9.39 \\
\hline Scientific research and technical services & 5 & -4.96 & -4.88 \\
\hline Household services, repair, and other & 5 & -1.33 & -1.24 \\
services & & & 4.11 \\
\hline Education & 5 & 4.07 & -6.68 \\
\hline Health and social services & 5 & -6.73 & -0.91 \\
\hline Culture, sports, and entertainment & $5-20$ & -0.96 & \\
\hline
\end{tabular}

Note: Since sales revenue is used to calculate the business tax, for comparability, the sales revenue is the denominator in the calculation of the effective tax rate here; When there are several business tax rates for one sector, we choose the relatively larger one. 
means the reduction of the input tax for other industries, so the effective tax rate in other industries increased: for example, the effective tax rate in the manufacturing industry rose by about $1.1 \%$.

Table 3 shows the data on the effective tax rate of the original business tax industry. The tax rate is not affected by the value-added tax transformation, but there were increases and decreases after the B2V reform. The effective tax rate for transport, storage, and post as well as real estate is higher than the original business tax rate, the effective tax rate for these spheres is now $7.82 \%$. At the same time, the effective tax rates for other industries have been reduced to different extents, some even to negative tax rates, for example, $-7.22 \%$ for hotels and catering services. This is due to the difference between the statutory tax rate and the deduction rate: the higher is the statutory tax rate and the lower is the deduction rate, the higher is the effective tax rate. For example, the intermediate investment in real estate accounts for only about $25 \%$ of the total output while the statutory tax rate is as high as $11 \%$, so the effective tax rate is relatively high. Regardless of the original business tax or VAT industry, the overall trend is a decrease in the effective tax rate. Only the industries with a higher statutory tax rate and a lower deduction ratio will show an increase. Due to the decrease of input deductions, the effective tax rate in the original business industries increased by $0.1 \%$ after the simplification and consolidation of the tax rate.

\subsection{Nominal tax burden}

The nominal tax burden is the most commonly used and the most easily measured tax burden indicator; it is the tax actually paid by taxpayers after taking into account many practical factors based on the effective tax rate. The nominal tax burden is affected by many practical factors and it demonstrates the same general trend as the effective tax rate, although it may deviate from the direction of the effective tax rate to some extent. Table 4 summarizes the nominal tax burden of all

The nominal tax burden in all sectors from 2008 to 2015

\begin{tabular}{|c|c|c|c|c|c|c|c|c|}
\hline \multirow{3}{*}{ Sector } & \multicolumn{8}{|c|}{ Nominal tax burden $(\%)$} \\
\hline & \multicolumn{4}{|c|}{$\begin{array}{l}\text { Before and after VAT } \\
\text { transformation }\end{array}$} & \multicolumn{4}{|c|}{$\begin{array}{l}\text { Before and after the B2V } \\
\text { reform }\end{array}$} \\
\hline & 2008 & 2009 & 2010 & 2011 & 2012 & 2013 & 2014 & 2015 \\
\hline Mining & 12.09 & 12.50 & 13.45 & 13.66 & 14.22 & 12.46 & 11.82 & 9.30 \\
\hline Manufacturing & 10.37 & 10.11 & 9.28 & 8.48 & 8.67 & 8.56 & 8.42 & 8.45 \\
\hline $\begin{array}{l}\text { Production and supply of electricity, heat, } \\
\text { gas, and water }\end{array}$ & 21.74 & 19.34 & 14.71 & 14.44 & 14.92 & 15.85 & 16.84 & 17.39 \\
\hline Construction & 8.28 & 8.55 & 9.15 & 9.50 & 10.11 & 10.51 & 10.79 & 11.22 \\
\hline Wholesale and retail trade & 12.72 & 13.64 & 14.10 & 13.44 & 11.73 & 11.26 & 10.34 & 9.98 \\
\hline Transport, storage and post & 4.33 & 4.18 & 4.40 & 4.56 & 4.72 & 4.74 & 4.48 & 4.03 \\
\hline Hotels and catering & 5.04 & 5.16 & 5.51 & 6.06 & 5.92 & 5.36 & 4.70 & 4.24 \\
\hline Information transmission, software, and IT & 4.39 & 4.56 & 4.84 & 5.04 & 5.15 & 4.98 & 5.45 & 4.67 \\
\hline Financial intermediation & 7.63 & 6.80 & 6.59 & 7.08 & 8.19 & 7.78 & 8.25 & 7.96 \\
\hline Real estate & 11.68 & 12.50 & 13.14 & 12.76 & 12.50 & 14.40 & 14.22 & 13.95 \\
\hline Leasing and business services & 10.67 & 10.11 & 11.07 & 11.96 & 10.90 & 10.55 & 10.34 & 10.91 \\
\hline Scientific research and technical services & - & - & - & - & 4.44 & 4.35 & 4.72 & 4.69 \\
\hline $\begin{array}{l}\text { Household services, repair, and other } \\
\text { services }\end{array}$ & 8.36 & 9.50 & 9.05 & 9.46 & 11.64 & 11.35 & 9.86 & 7.95 \\
\hline Education & 0.18 & 0.19 & 0.20 & 0.21 & 0.24 & 0.24 & 0.24 & 0.22 \\
\hline Health and social services & 0.17 & 0.14 & 0.05 & 0.07 & 0.10 & 0.07 & 0.08 & 0.07 \\
\hline Culture, sports, and entertainment & 5.46 & 5.09 & 5.20 & 5.38 & 5.32 & 4.81 & 4.05 & 3.46 \\
\hline $\begin{array}{l}\text { Public management, social security, and } \\
\text { social organizations }\end{array}$ & 0.45 & 0.45 & 0.55 & 0.58 & 0.64 & 0.75 & 0.76 & 0.91 \\
\hline
\end{tabular}


sectors from 2008 to $2015^{13}$. The data from 2009 to 2011 reflect the changes in the nominal tax burden before and after the VAT transformation, and the data from 2012 to 2015 reflects the changes in the nominal tax burden before and after the B2V reform.

It can be seen from the analysis in Table 4 that before and after the VAT transformation, the effect of a nominal tax reduction is far from being obvious. The nominal tax burdens on manufacturing and the production and supply of electricity, heat, gas, and water decreased by $1.7 \%$ to $4.9 \%$, while in the mining industry this figure increased by approximately 1.1\% after 2009. These are not exactly the same trends as the ones we observed in the case of the effective tax rate. The most important practical factor that has led to this phenomenon is the continuous growth of the leviable rate since 2008 [24, p. 17], which can be seen judging by the same general upward trend in the nominal tax burden of other original business tax industries.

There is an overall decline in the nominal tax burden before and after the B2V reform while a few industries demonstrated an increase or fluctuations. The B2V reform did not cover the construction, real estate, financial intermediation, and life service industries until 2015, while the nominal tax burden of those spheres that had already experienced the reform, such as transportation, storage, and post industries, dropped by $0.69 \%$ in the last four years. The burden on culture, sports, and entertainment industries dropped by $1.86 \%$, and the nominal tax burden on the mining and manufacturing industries also decreased to some extent; the mining industry in particular decreased by $4.92 \%$, which is consistent with the 500 billion yuan cut in tax revenue. Of course, some industries demonstrate the opposite trend: the nominal tax burden of the production and supply of electricity, heat, gas, and

${ }^{13}$ In order to make our comparison of the indicator before and after the B2V reform more consistent, we have included the business tax and VAT in the calculation of the nominal tax burden. water has increased by $2.48 \%$ since $2012^{14}$. Therefore, the nominal tax burden is the combination of the effective tax rate and practical factors, which means that practical factors could make the nominal tax rate deviate from the direction of the effective tax rate to some extent, but the overall trend is still the same.

\subsection{Actual tax burden}

The actual tax burden involves tax burden transfer factors, which are very difficult to calculate, so it is rarely used either theoretically or practically. However, we cannot deny that the actual tax burden is actually the tax burden borne by taxpayers. According to the calculations of Nie Haifeng and Liu Yi [25, p. 1389] and Yin Yinxuan and Yan Shengli [26, p. 23], $60 \%$ to $80 \%$ of China's indirect tax burden is borne by consumers, and only $20 \%$ to $40 \%$ is borne by companies. According to Formula (3)

$$
r_{3}=(1-\delta) r_{2}
$$

the actual tax burden can be calculated based on the nominal tax burden. Taking the period from 2012 to 2015 as an example and assuming that $30 \%$ of the VAT is borne by the company ${ }^{15}$, we can make calculations according to the formula:

$$
r_{3}=0.3 r_{2} \text {. }
$$

The calculation results are shown in Table 5.

14 One of the main practical reasons for the rise of tax burden is that the production and supply of electricity, heat, gas and water industries have been divided into three types of enterprises: the VAT, business tax and mixedbusiness industries. The quality of procurement management is the key determinant of the tax burden of the production and supply of electricity, heat, gas, and water. So, the rise of the leviable rate, the adaptation period of the new tax system and the quality reduction all cause the rise of the nominal tax burden.

${ }^{15}$ An implicit assumption is that the tax burden shifting coefficient is not affected by the reform, is only affected by factors such as supply and demand elasticity, reaction period, and tax attribute. There is no relevant literature research to prove that the tax burden shifting coefficient will be affected by the reform. Although these factors may be affected by reforms, they do not affect the analytical thinking. 
The actual tax burden in all sectors from 2012 to 2015

Table 5

\begin{tabular}{|l|r|r|r|r|}
\hline \multirow{2}{*}{ Sector } & \multicolumn{3}{|c|}{ Actual tax burden (\%) } \\
\cline { 2 - 5 } & $\mathbf{2 0 1 2}$ & $\mathbf{2 0 1 3}$ & $\mathbf{2 0 1 4}$ & $\mathbf{2 0 1 5}$ \\
\hline Mining & 4.26 & 3.74 & 3.54 & 2.79 \\
\hline Manufacturing & 2.60 & 2.57 & 2.53 & 2.54 \\
\hline Production and supply of electricity, heat, gas, and water & 4.47 & 4.76 & 5.05 & 5.22 \\
\hline Construction & 3.03 & 3.15 & 3.24 & 3.37 \\
\hline Wholesale and retail trade & 3.52 & 3.38 & 3.10 & 2.99 \\
\hline Transport, storage, and post & 1.42 & 1.42 & 1.35 & 1.21 \\
\hline Hotels and catering & 1.78 & 1.61 & 1.41 & 1.27 \\
\hline Information transmission, software, and IT & 1.54 & 1.50 & 1.64 & 1.40 \\
\hline Financial intermediation & 2.46 & 2.33 & 2.47 & 2.39 \\
\hline Real estate & 3.75 & 4.32 & 4.27 & 4.18 \\
\hline Leasing and business services & 3.27 & 3.16 & 3.10 & 3.27 \\
\hline Scientific research and technical services & 1.33 & 1.31 & 1.41 & 1.41 \\
\hline Household services, repair, and other services & 3.49 & 3.41 & 2.96 & 2.38 \\
\hline Education & 0.07 & 0.07 & 0.07 & 0.07 \\
\hline Health and social services & 0.03 & 0.02 & 0.02 & 0.02 \\
\hline Culture, sports, and entertainment & 1.60 & 1.44 & 1.21 & 1.04 \\
\hline Public management, social security, and social organizations & 0.19 & 0.22 & 0.23 & 0.27 \\
\hline
\end{tabular}

Compared to the nominal tax burden shown in Table 4, the actual tax burden borne by the company was reduced much more, to a maximum of $5 \%$. This picture is entirely different from the research results given in the "death tax rate" report that said that companies bear a high tax burden. It is clear that the "death tax rate" does not take into account the difference between corporate payments and the tax actually borne by companies. There are also increases and fluctuations in the actual tax burden in some sectors, such as the production and supply of electricity, heat, gas and water, information transmission, software and IT. From the perspective of the actual tax burden, the Ministry of Finance reported that the tax cut of the 2016 B2V reform was about 500 billion, out of which only 150 billion yuan corresponded to the tax cut enjoyed by enterprises while the other 350 billion was transferred to consumers.

\subsection{Explanation of the two puzzles}

The two questions mentioned at the beginning of the article are as follows: (1) Why have there been so many contradictory empirical research findings and views about tax burdens since the B2V reform? (2) Why are companies so concerned about the VAT reform? Our analysis of the four types of tax burdens provides us with the answers to these questions.

Table 6 summarizes the results of the above-mentioned analysis. The statutory tax rate did not change during the VAT transformation, while the statutory tax rate in most of the original business tax industries increased after the B2V reform ${ }^{16}$. The statutory tax rate of $13 \%$ was replaced by $11 \%$ when the tax rate was simplified and consolidated. The effective tax rate decreased due to the expansion of deduction strategies after the VAT transformation. After the B2V reform and the simplification and consolidation of the tax rate, the effective tax rate showed both downward and upward tendencies.

To be more specific, the effective tax rate decreased in the original VAT industries while in the original business tax industries it demonstrated upward and downward tendencies. In other words, the nominal tax burden and the actual tax burden can decrease or increase depending on the industry.

16 The original business tax rate of some entertainment industries may be higher than the current value-added tax rate after the "replacing business tax with VAT" reform. 
The changes of all tax burden indicators after three VAT reforms

Table 6

\begin{tabular}{|l|l|l|l|}
\hline \multicolumn{1}{|c|}{$\begin{array}{c}\text { Tax burden } \\
\text { indicator }\end{array}$} & \multicolumn{1}{c|}{$\begin{array}{c}\text { VAT } \\
\text { transformation }\end{array}$} & \multicolumn{1}{c|}{ B2V reform } & \multicolumn{1}{c|}{$\begin{array}{c}\text { Simplification and } \\
\text { consolidation of tax rate }\end{array}$} \\
\cline { 2 - 4 } & - & Increase & Decrease \\
\hline Statutory tax rate & Decrease & $\begin{array}{l}\text { Decrease in the original } \\
\text { VAT industries and most } \\
\text { of the original business } \\
\text { tax industries }\end{array}$ & $\begin{array}{l}\text { Some increase and others } \\
\text { decrease }\end{array}$ \\
\hline Nominal tax burden & $\begin{array}{l}\text { Some increase and } \\
\text { others decrease }\end{array}$ & $\begin{array}{l}\text { Some increase and others } \\
\text { decrease }\end{array}$ & $\begin{array}{l}\text { Some increase and others } \\
\text { decrease* }\end{array}$ \\
\hline Actual tax burden & $\begin{array}{l}\text { Some increase and } \\
\text { others decrease }\end{array}$ & $\begin{array}{l}\text { Some increase and others } \\
\text { decrease }\end{array}$ & $\begin{array}{l}\text { Some increase and others } \\
\text { decrease* }^{*}\end{array}$ \\
\hline
\end{tabular}

Note: The * mark on the nominal and actual tax burden means that there are no data to prove it yet, but the results can be deduced from the above-described analysis.

Thus, if we look at Table 6, the first puzzle can be explained. One reason is the difference in measurement indicators, and the other is the differences in industries and research objects. Different indicators may lead to different results. For example, when we examine the effect of the $\mathrm{B} 2 \mathrm{~V}$ reform, there is a perceived rise from the perspective of the statutory tax rate, while in case of the effective tax rate, there is a fluctuation. The same is true of the nominal and actual tax burden. Moreover, by focusing on different industries and objects, we may get different results even within the same measurement indicator.

We can also explain the second puzzle regarding why companies are so concerned about the B2V reform. As a general excise tax, theoretically, the VAT should be borne by consumers, but companies also bear some of the burden as well. Since the reform concerns the operating costs, it is reasonable for companies to pay attention to $\mathrm{it}^{17}$.

\section{Conclusion}

Since China successfully launched two VAT reforms, the country's practical experience of VAT management has drawn significant attention both at home and abroad. However, there are different estimations of the VAT burden in the Chinese academia, business and government

${ }^{17}$ There are some other reasons, for example, the higher subjective corporate tax burden. But in this article we are only dealing with the objective reasons. circles, and these differences can influence the scientific judgment concerning the effectiveness of the VAT reform. Focusing on the above-mentioned questions related to this problem, this article clarifies the concept of the VAT tax burden; the authors hold the opinion that we should have a full understanding of tax burden on the macro-economic, industrial, and micro-economic levels as well as its four indicators - the statutory tax rate, effective tax rate, nominal tax burden, and actual tax burden indicators. By calculating and measuring the effect of tax cuts after the VAT transformation, the B2V reform and the simplification and consolidation of the tax rate, we can provide more data to be considered for further reforms.

1. The VAT tax burden indicator can be divided into four types according to the combination of the general principles of value-added taxation and more practical considerations: the statutory tax rate at the macro-level, the effective tax rate at the mid-level, the nominal tax burden, and the actual tax at the micro-level. The statutory tax rate is the proportion of the VAT levied by the state according to the corresponding legislation. Taking into account the special deduction structure of the VAT, the effective tax rate refers to the theoretical ratio of the VAT payable calculated according to taxation laws and the tax base. The nominal tax burden takes into account certain practical factors to measure the tax burden borne by taxpayers. And finally, the actual tax burden takes into account 
both the practical factors and the shifting factors and thus refers to the VAT actually paid by the taxpayer.

2. The two questions mentioned above are the following: (a) Why has there been so much controversy surrounding tax burden in research literature since the B2V reform? (b) Why are companies so concerned about the VAT reform? The first question can be explained by the differences in measurement indicators and research industries; tax burden can vary depending on indicators and industries. The objective reason for the second question is that companies actually bear onethird of the tax burden, and the reform truly affects their operation costs.

3. All indicators other than the statutory tax rate caused a decline in tax burden: this effect was even more obvious after the B2V reform. Meanwhile, the tax burden fluctuated in all sectors after the VAT transformation and the simplification and consolidation of the tax rate, and in this case, the tax cut effect was not obvious. To be more specific, the effective tax rate in all original VAT industries and some of the original business tax industries decreased because of the expansion of deduction strategies, while there was also a rise in the tax rate for some business tax industries due to the higher statutory tax rate and lower deduction rate. Practically in all the sectors, the actual tax burden and nominal tax burden decreased; only in a few sectors, the tax burden fluctuated or increased.

Since China joined the major international trend for tax cutting, its tax policy has changed from that of the "stable macro-tax burden" to "tax reduction." However, in order to ensure real tax cuts, it is necessary to consider a number of factors - deductible factors, practical factors and tax burden shifting factors and finally act on the actual tax burden, which makes the whole process not very efficient. Thus, we can conclude that it is not a very good strategy considering the current financial conditions. The following measures in the post-reform period will help the government decrease the tax burden efficiently without sacrificing too much fiscal revenue:

1. Establish a VAT retained refund system. The VAT retained in a company is the key factor that allows the VAT tax burden not to shift to the next link, so the VAT may become the operating cost and economic burden on the company. A VAT retained refund system means that the tax retained in the company can be cut and be connected into the VAT deduction chain, thus allowing us to reduce the actual tax burden efficiently.

2. Increase the actual deductible rate of the company. Such practical factors as the lack of familiarity with the tax system, careless invoice preservation, and the lack of tax awareness will make the actual deduction rate lower than the theoretical deductible rate. For all companies, a lower deductible rate will lead to an increase in the nominal and actual tax burden. We can take a two-pronged approach to optimization: the first is tax management, improvement of the quality of tax services, and optimization of the management and deduction procedures. The other relates to taxpayers. We need to enhance their awareness of taxation policies so that they had a better understanding of the VAT system and could avoid unnecessary tax risks. This will increase the actual deductible rate and reduce the actual tax burden.

\section{References}

1. Fan Y. The tax cut reduction effect of VAT Reform in China. China Economic Weekly. 2017;19:74-77.

2. Keqiang L. Report on the Work of the Government. Delivered at the Fourth Session of the $12^{\text {th }}$ National People's Congress of People's Republic of China on March 5, 2016. Available at: http://english.gov.cn/premier/news/2016/03/17/content 281475309417987.htm

3. Liu D. M., Zhang B. Q. Analysis of the Impact of "VAT Reform" on the Tax Burden of Commercial Banks. Taxation Research. 2015;(5):107-112. 
4. Jiang M. Y. The Impact of VAT "Expansion" Reform on Industry Tax Burden - Based on the Analysis of Input-Output Table. Journal of Central University of Finance E Economics. 2011;(2):11-16.

5. Tian Z. W., Hu Y. J. Dynamic Analysis of the Impact of "Calculation Reform" on Tax Burden in Various Industries - Based on Analysis of CGE Model. Collected Essays on Finance and Economics. 2013;(4):29-34.

6. Tong J. Z., Su G. C., Wei Z. H. "Replacing the business tax with VAT" Reform, Enterprise Bargaining Power and Enterprise Actual Turnover Tax Burden - An Empirical Study Based on Chinese Listed Companies. Finance \& Trade Economics. 2015;(11):14-26.

7. Chen X. G. Different Effective Tax rates of VAT and Efficiency Loss: With Some Implications for "Replacing the Business Tax with VAT". Social Sciences in China. 2013;(8):67-84, 205-206.

8. Fan Z. Y., Peng F. The Tax Reduction Effect and Labor Division Effect of "Replacing the Business Tax with VAT": Based on the Perspective of Industrial Interconnection. Economic Research Journal. 2017;52(2):82-95.

9. Wang Y. L., Li Y. K. Research on the Impact of "Replacing the Business Tax with VAT" on the Tax Burden and Profit Level of the Transportation Industry - Taking the Listed Companies in Shanghai as an Example. Public Finance Research. 2014;(5):41-45.

10. Huang G. L. Analysis of the Impact of "Replacing the Business Tax with VAT" on the Tax Burden of Transportation Enterprises. Finance \& Accounting for Communications. 2013;(11):8-12.

11. Yang Z. Y. The Tax Burden Problem in the "Replacing the Business Tax with VAT". China Finance and Economics Newspaper. 2012;(3).

12. Li X. C. Discussion on Tax Planning of Road Transport Enterprises after "Replacing the Business Tax with VAT". Modern Business. 2012;(8):194-195.

13. Zong S. H., Zhou S. D. Estimated Tax Burden Changes in the Real Estate Industry after "Replacing the Business Tax with VAT". Finance and Accounting Monthly. 2013;(13):105-106.

14. Yu X. B., Ke X. The Impact of "Replacing the Business Tax with VAT" on Transportation Enterprises. Friends of Accounting. 2014;(22):119-121.

15. Li J. M. Study on the Impact of the "Replacing the Business Tax with VAT" on the Corporate Taxation and the Countermeasures. Scientific and technological innovation. 2016;(2):294-295.

16. Fu L.M. "Replacing the Business Tax with VAT" and Corporate Tax Burden - Evidence from Chinese Listed Companies. Zhejiang University; 2015.

17. Fan Y. An Empirical Study on the Impact of VAT Deduction System on Industry on Sector's Tax Burden. Finance \& Trade Economics. 2012;1:34-41.

18. Fullerton D. Which Effective Tax Rate? National Tax Journal. 1984;37(1):23-41.

19. Yang J. Z. Institutional Innovation: The Actual Tax Burden and Nominal Tax Burden of Tourism Enterprises. China Economist. 2003;(8):114-115.

20. Wang D. Sh., Dong L. H., Li X. Sh. Methods and Implications for Estimating Tax Loss in the UK. Foreign Taxation. 2009;8:46-50.

21. Ma N.Y., Application of Sweden's Tax Loss Estimation and Results. Foreign Taxation. 2012;5:46-49.

22. Matti Viren. Does the Value-Added Tax Shift to Consumption Prices? AUCO Czech Economic Review. 2009;3:123-142.

23. Smart M., Bird R. M. The Impact on Investment of Replacing a Retail Sales Tax with a Value-Added Tax: Evidence from Canadian Experience. Working Papers. 2008;62(4):591-609.

24. Zhou L. A., Liu C., Li X. The Mystery of Taxation Efforts, Taxation Agencies and Tax Growth. China Economic Quarterly. 2012;11(1):1-18.

25. Nie H. F., Liu Y. The Evolution of the Indirect Tax Burden of Urban Residents. China Economic Quarterly. 2010;9(4):1385-1402.

26. Yin Y.P., Yan S. L. The Fate of China's Indirect Tax and the Effect of Income Redistribution. Taxation Research. 2017;(4):20-26. 


\section{Acknowledgements}

Authors greatly appreciate Parshina Lika's contribution to this article, especially in the translation and proofread work.

\section{Authors}

Yong Fan - Ph.D, Professor, Secretary of Party Committee. School of Public Finance and Economics, Central University of Finance and Economics (Beijing, 102206, China); (D 0000-0002-1741-001X; e-mail: yongfan008@sina.com

Haonan Li - Postgraduate student, School of Public Finance and Economics, Central University of Finance and Economics (Beijing, 102206, China); (D) 0000-0001-7748665X; e-mail: 17310704731@163.com

Qinyao Zhu - Master Student, School of Public Finance and Economics, Central University of Finance and Economics (Beijing, 102206, China); (DD 0000-0002-36475652; e-mail: zqy112361@163.com

\section{For citation}

Fan Y., Li H., Zhu Q. Tax burden reduction and tax cuts in China's vat reform. Journal of Tax Reform. 2019;5(1):23-41. DOI: 10.15826/jtr.2019.5.1.058

\section{Article info}

Received July 7, 2018; accepted February 1, 2019

\section{Благодарности}

Авторы высоко ценят вклад Паршиной Лики в эту статью, особенно в переводе и корректуре.

\section{Информация об авторах}

Фан Юн - доктор наук, профессор, Секретарь парткома, Школа публичных финансов и экономики, Центральный университет финансов и экономики (Китай, 102206, Пекин); (DD 0000-0002-1741-001X; e-mail: yongfan008@sina.com

Ли Хаонан - аспирант, Школа публичных финансов и экономики, Центральный университет финансов и экономики (Китай, 102206, Пекин); (D) 0000-00017748-665X; e-mail: 17310704731@163.com

Джу Тсиняо - магистрант, Школа публичных финансов и экономики, Центральный университет финансов и экономики (Китай, 102206, Пекин); (D) 0000-00023647-5652; e-mail: zqy112361@163.com

\section{Аия цитирования}

Фан Ю., Ли Х., Джу Т. Налоговая нагрузка и снижение налогов в рамках реформы НДС в Китае // Journal of Tax Reform. 2019. Т. 5, № 1. С. 23-41. DOI: 10.15826/ jtr.2019.5.1.058

\section{Информация о статье}

Дата поступления 7 июля 2018 г.; дата принятия к печати 1 феераля 2019 г. 